
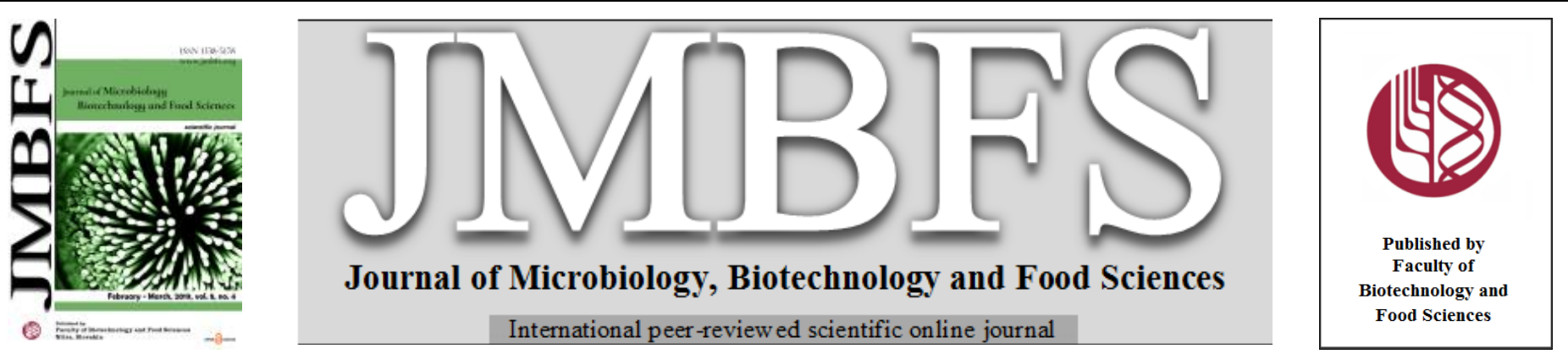

\title{
STORAGE OF EXTRA VIRGIN OLIVE OIL AND ITS IMPACT ON FATTY ACID LEVELS
}

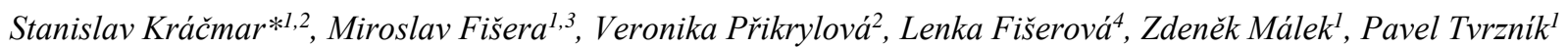 \\ Address(es): \\ ${ }^{1}$ College of Business and Hotel Management Brno, Bosonožská 9, 62500 Brno, Czech Republic, +420 547218247. \\ ${ }^{2}$ Thomas Bata University in Zlín, Faculty of Technology, Department of Food Technology, Vavrečkova 275, 76001 Zlín, Czech Republic. \\ ${ }^{3}$ Thomas Bata University in Zlín, Faculty of Technology, Department of Food Analysis and Chemistry, Vavrečkova 275, 76001 Zlín, Czech Republic. \\ ${ }^{4}$ Brno University of Technology, Faculty of Chemistry, Institute for Chemistry and Technology of Environmental Protection, Purkyňova 118, CZ-612 00 Brno, Czech \\ Republic, E-mail: fiserova@fch.vut.cz.
}

*Corresponding author: standa1948@gmail.com ; kracmar@utb.cz

doi: 10.15414/jmbfs.2019.8.5.1228-1230

\section{ARTICLE INFO}

Received 7. 11. 2018

Revised 17. 1. 2019

Accepted 23. 1. 2019

Published 1. 4. 2019

Regular article

OPEN OACCESS

\section{ABSTRACT}

Peroxide value, acid value, and fatty acid content were monitored during two-year storage in the following products: Luccese Olio extra vergine d'oliva (LOEVDO), Blanqueta extra-virgin olive oil (BEVOO) and Agrocreta extra-virgin olive oil (AEVOO). In LOEVDO and BEVOO, peroxide value increased by $50 \%$; AEVOO showed $80 \%$ growth. Maximum acid value was found solely in LOEVDO $(<0.8 \%)$. All the analyzed samples contained almost identical proportions of fatty acids. Minute amount of lauric acid (C 12:0) was indentified in BVEOO samples only. The two-year storage resulted in growth of oleic and stearic acid levels and in decrease of linoleic and palmitic acids concentration. The percentage of SAFA, MUFA and PUFA complied with recommended levels.

Keywords: extra virgin olive oil, storage, peroxide value, acid value, fatty acids, oleic acid, SAFA, MUFA, PUFA

\section{INTRODUCTION}

Due to potential health benefits as well as to its specific organoleptic properties (Rodrigues et al., 2015), demand for high-quality extra-virgin olive oil has been rising recently. Quality of virgin olive oil is given by the following factors: variety, region of growing, climate, ripeness, storage period, and type of packaging. Phenolic substances enhance its nutritional, biological and sensory qualities, and its shelf life; moreover, they also improve its resistance to autooxidation (Muco et al., 2012; Albot, 2015; Kalogeropoulos and Kaliora, 2015; Koidis and Boskou, 2015).

More than $90 \%$ of olive oil is found in olive fruit mesocarp (Korbelář and Endris, 1990; Lopez et al., 2014); it contains mostly triacyl glycerols such as triglycerides fats responsible for hydrophobicity. The oil includes also small amount of free fatty acids (FFA), glycerol, phosphatides, pigments, flavourings, sterols, phenolic substances, and microscopic olive particles contributing to its uniqueness (Boskou, 2006; Muco et al., 2012; Lopez et al., 2014).

As reported by Albot (2015), Kalogeropoulos and Kaliora (2015), and Koidis and Boskou (2015), olive oil decomposes in the course of its aging; quite substantial amount of oleic acid is formed, acid value grows and flavour weakens. Low acidity contributes to long shelf-life of extra-virgin olive oils. By increasing proportion of free fatty acids, oxygen exerts negative influence on sensory properties of oil. Temperatures above $25^{\circ} \mathrm{C}$ together with light accelerate its going rancid and cause decrease of antioxidant levels, too. At room temperature and in the shade, olive oil can be kept in a closed vessel for two years. After opening, oil should be consumed within a short period, since oil keeps its qualities for approximately one year and then it goes rancid.

Several studies (Anonymous 1, 1991; Frohn, 2002; Anonymous 2, 2013; Dalmia and Perkins, 2014; Peri, 2014) deal with quality of olive oil, factors guaranteeing its authenticity, methods employed for analysis of various oil qualities and with definition of its chemical and organoleptic properties. According to production procedure employed and to acid content, a European directive (Anonymous 2, 2013) classifies olive oil into the following categories:

A) Extra-virgin olive oil. A natural cold-pressed oil without addition of chemicals or biochemical substances; it is characterized by acid value lower than $0.8 \%$.

B) Virgin olive oil. A natural product obtained by pressing that is not treated with chemicals; its acid value is higher than $1 \%$.

C) Olive oil. It contains mixture of refined and virgin olive oil.
Frohn (2002) and Kotsiou and Tasioula-Margari (2016) recommend storage of olive oil in well tighten packagings such as dark glasses or cans at temperatures ranging between $10^{\circ} \mathrm{C}$ to $16^{\circ} \mathrm{C}$ preferably in airy, dark, and cool rooms. Kotsiou and Tasioula-Margari (2016) regard places close to oven or induction cooktop the worst sites for oil storage. Permanent opening and closing oil keeping bottles and their fullness exert negative influence on oil qualities (Piscopo and Poi, 2012). Bigger amounts of oil can be frozen (Raffo et al., 2015; Korifi $\boldsymbol{e t}$ al., 2016). At lower storage temperatures, oil gets thick showing soft butter consistence and it becomes turbid due to agglomerates of opaque particles. After heating it, turbidity disappears and the oil regains its properties and nutritive values (Frohn, 2002).

Research on changes of physico-chemical properties of extra virgin oil stored for five month was implemented by Salek $\boldsymbol{e t}$ al. (2017); another researcher (Orey, 2009) studied natural effects of extra virgin oil.

The objective of our study was to monitor influence of two-year storage of selected extra virgin oils (Luccese Olio extra vergine d'oliva, Italy; Blanqueta extra virgin olive oil, Spain; and Agrocreta extra virgin olive oil, Spain) on peroxide and acid value and on content of selected fatty acids.

\section{MATERIAL AND METHODS}

\section{Characteristics of samples}

For each type of olive oil, three packagings from identical batch with identical minimum shelf-life were purchased in supermarkets. The oils were stored in a dark and dry place at $20^{\circ} \mathrm{C}$.

The following oils were subjected to the study:

Luccese Olio extra vergine d'oliva (LOEVDO) - Extra virgin olive oil (Italy); best consumed before $11 / 2015$. This prime selection olive oil is manufactured by mechanical means directly from olive fruits.

Blanqueta extra virgin olive oil (BEVOO) - Best quality extra virgin olive oil (Spain); best consumed before 10/2015. BEVOO is obtained by mechanical pressing without using chemical additives.

Agrocreta extra virgin olive oil (AEVOO) - Prime quality extra virgin olive oil (Greece); produced directly from olive fruits by mechanical processing; best consumed before 10/2015. 


\section{Determination of peroxide value and acid value}

Peroxide value (meq $\mathrm{O}_{2} \cdot \mathrm{kg}^{-1}$ ) specifies amount of oxygen that is able to oxidize iodide to iodine and Acid value shows amount of $\mathrm{KOH}\left(\mathrm{mg}^{-1} \mathrm{~g}^{-1}\right)$ essential for neutralization of free fatty acids. Both of these parameters were determined according to the literature methodology (Chakrabarti, 2003).

\section{GC Analyses of FAMEs}

Lipids including fatty acids (FAs) are considered as essential human nutrients that can be classified according to absence or presence of unsaturated bonds into the following categories: saturated fatty acids (SFAs), monounsaturated fatty acids (MUFA), and polyunsaturated fatty acids (PUFA).

Human body can produce both SFAs and MUFAs, but essential fatty acids (EFAs), a subcategory of PUFAs with first double bond located at C3 or C6, cannot be synthesized by humans (Grofová, 2010)

Fatty acids were determined by gas chromatography (GC) via their methyl esters (FAMEs) in lipid extracts obtained using the method described hereafter without drying. Solution of sodium hydroxide in methanol $(0.5 \mathrm{M}, 4 \mathrm{ml})$ was added to lipid extract obtained from $2 \mathrm{~g}$ of a sample into a $250 \mathrm{ml}$ flask. The flask was closed with a stopper and heated under nitrogen atmosphere in a heating block (LTHS 250, Brněnská Drutěva, Brno, Czech Republic). As a methylation agent, freshly prepared $15 \%$ solution of boron trifluoride in methanol $(5 \mathrm{~mL})$ was added then. After two minutes, heptane $(15 \mathrm{~mL})$ and saturated solution of sodium chloride $(2 \mathrm{~mL})$ were added and the sample was removed from the heating block. After adding heptane $(15 \mathrm{~mL})$ and saturated solution of sodium chloride $(40 \mathrm{~mL})$ to extract FAMEs, the phases were agitated and then subsequently separated and washed with saturated solution of sodium hydroxide $(40 \mathrm{~mL})$. The heptane phase was separated and anhydrous sodium sulphate was added then.

Determination of FAMEs content was implemented via a Shimadzu GC-2010 gas chromatograph equipped with flame ionization detector (FID) and a HP-88 (Agilent Technologies, Englewood, Colorado, USA) capillary column (100 m $\times$ $0,25 \mathrm{~mm}, 88 \%$ cyanopropyl- arylpolysiloxane stationary phase with film thickness of $0.25 \mu \mathrm{m})$. The analysis was performed under the following conditions: injection volume $1.0 \mu \mathrm{L}$; the temperature of injection port $250{ }^{\circ} \mathrm{C}$ with the split ratio 1: 100; nitrogen used as a carrier gas. Temperature program of the column included the undermentioned parameters: temperature $80^{\circ} \mathrm{C} / 5 \mathrm{~min}$, $200^{\circ} \mathrm{C} / 30 \mathrm{~min}$, and $250^{\circ} \mathrm{C} / 15 \mathrm{~min}$. Identification of FAMEs was conducted by comparison of their retention time with the values of 37 FAMEs contained in a reference standard. As an internal standard, methyl undecanoate was used for quantification of FAMEs. The determined FA content is expressed as a percentage of the total FAMEs amount.

\section{RESULTS AND DISCUSSION}

Table 1 shows changes of peroxide and acid values of selected extra-virgin olive oils during storage.

Table 1 Changes of Peroxide value (meq $\left.\mathrm{O}_{2} \cdot \mathrm{kg}^{-1}\right)$ and Acid value $\left(\mathrm{mg} \mathrm{KOH} \cdot \mathrm{g}^{-1}\right)$ in selected extravirgin olive oils during storage (mean \pm S.D.).

\begin{tabular}{lllllll}
\hline & ${\text { meq } \mathrm{O}_{2} \cdot \mathrm{kg}^{-}}^{-}$ & & & ${\mathrm{mg} \mathrm{KOH} . \mathrm{g}^{-1}}$ & \\
& LOEVDO & BEVOO & AEVOO & LOEVDO & BEVOO & AEVOO \\
\hline $10 / 2014$ & $1.49 \pm 0.12$ & $1.36 \pm 0.08$ & $4.07 \pm 0.18$ & $0.69 \pm 0.08$ & $0.65 \pm 0.10$ & $0.79 \pm 0.12$ \\
$4 / 2015$ & $1.58 \pm 0.18$ & $1.51 \pm 0.12$ & $4.97 \pm 0.22$ & $0.70 \pm 0.10$ & $0.80 \pm 0.08$ & $1.02 \pm 0.22$ \\
$1 / 2016$ & $2.23 \pm 0.19$ & $2.61 \pm 0.21$ & $5.19 \pm 0.38$ & $0.79 \pm 0.19$ & $0.90 \pm 0.17$ & $1.54 \pm 0.31$ \\
\hline
\end{tabular}

Caption: LOEVDO - Luccese Olio extra vergine d'oliva; BEVOO - Blanqueta extra virgin olive oil; AEVOO -

Agrocreta extra virgin olive oil

Peroxide value increased by $50 \%$ in LOEVDO and BEVOO and by $80 \%$ in AEVOO. The EU 299/2013 directive specifies maximum peroxide values for individual types of olive oil in the following way: extra-virgin olive oil $\leq 20 \mathrm{meq}$ $\mathrm{O}_{2} / \mathrm{kg}$ and olive pomace oil $\leq 15 \mathrm{meq} \mathrm{O}_{2} / \mathrm{kg}$. For practical reasons, the acid value is now expressed as the acidity of the oil, which is the amount of free fatty acids to the total amount of fatty acids in \% (AOCS Official Method, 2009). The socalled acidity can be calculated from the acid number. It is recommended to keep acidity of extra-virgin olive oil below $<0.8 \%$. Only acidity of LOEVDO did not go beyond the maximum recommended value. Muco et al. (2012) suggest that acidity in virgin olive oil should not exceed $2 \% \leq$. Acidity in all the studied samples fulfilled the above limit.

Fourteen fatty acids (Table 2) were detected during two-year storage in extravirgin olive oils.

$\underline{\text { Table } 2 \text { Percentage of fatty acids detected in selected extra-virgin olive oils during two-year storage }}$

\begin{tabular}{|c|c|c|c|c|c|c|c|c|c|}
\hline \multirow{2}{*}{$\begin{array}{l}\text { Fatty acid } \\
\text { Month/year }\end{array}$} & \multicolumn{3}{|c|}{ LOEVDO } & \multicolumn{3}{|c|}{ BEVOO } & \multicolumn{3}{|c|}{ AEVOO } \\
\hline & $10 / 2014$ & $04 / 2015$ & $01 / 2016$ & $10 / 2014$ & $04 / 2015$ & $01 / 2016$ & $10 / 2014$ & $04 / 2015$ & $01 / 2016$ \\
\hline C12:0 & ND & ND & ND & 0.02 & 0.02 & 0.02 & ND & ND & ND \\
\hline C14:0 & 0.02 & 0.02 & 0.02 & 0.02 & 0.02 & 0.02 & 0.01 & 0.01 & 0.01 \\
\hline C15:0 & ND & ND & ND & ND & ND & ND & ND & ND & ND \\
\hline C16:0 & 12.52 & 12.52 & 12.52 & 11.71 & 11.71 & 11.71 & 11.65 & 11.65 & 11.65 \\
\hline C16:1(cis-9) & 0.90 & 0.90 & 0.90 & 0.69 & 0.59 & 0.59 & 0.68 & 0.68 & 0.68 \\
\hline C17:0 & 0.08 & 0.08 & 0.08 & 0.04 & 0.04 & 0.04 & 0.05 & 0.05 & 0.05 \\
\hline C17:1(cis-10) & 0.13 & 0.13 & 0.13 & 0.06 & 0.06 & 0.06 & 0.08 & 0.08 & 0.08 \\
\hline C18:0 & 2.94 & 2.94 & 2.94 & 2.57 & 2.74 & 2.79 & 2.79 & 2.79 & 2.79 \\
\hline C18:1(trans-9) & 0.02 & 0.02 & 0.02 & 0.02 & 0.02 & 0.03 & 0.04 & 0.04 & 0.04 \\
\hline C18:1(cis-9) & 72.45 & 72.45 & 72.45 & 76.17 & 76.72 & 76.72 & 75.90 & 75.90 & 75.90 \\
\hline C18:2(all-cis-9,12) & 9.53 & 9.53 & 9.53 & 7.15 & 7.03 & 7.03 & 7.35 & 7.35 & 7.35 \\
\hline C18:3(all-cis-9,12,15) & 0.25 & 0.25 & 0.25 & 0.29 & 0.29 & 0.29 & 0.27 & 0.27 & 0.27 \\
\hline $\mathrm{C} 20: 0$ & 0.42 & 0.42 & 0.42 & 0.42 & 0.41 & 0.41 & 0.47 & 0.47 & 0.47 \\
\hline C20:1(cis-11 & 0.75 & 0.75 & 0.75 & 0.74 & 0.74 & 0.73 & 0.73 & 0.73 & 0.73 \\
\hline
\end{tabular}

All the analyzed samples contained almost identical proportion of individual fatty acids; small amount of lauric acid (C 12:0) was found solely in BVEOO.

Oleic acid (C18:1 cis-9) showed to be the most abundant fatty acid; its percentage exceeded $70 \%$ in all the samples. Lesser amounts of the following acids were detected in the analyzed samples: heptanoic, heptadecanoic, arachidic, gondoic, and palmitoleic acid. These acids play important role in characterisation of individual cultivars, as reported by Muco et al. (2012)

A legislative directive (Anonymous 1, 1991) specifies maximum content of myristic $(0.1 \%)$, linolenic acid $(0.9 \%)$, arachidonic $(0.7 \%)$, eicosanic $(0.5 \%)$, behenic $(0.3 \%)$, and lignoceric $(0.5 \%)$ acids in extra-virgin olive oil. During two-year storage, no sample showed levels of myristic $(0.1 \%)$, linolenic $(0.9 \%)$ or eicosanic $(0.5 \%)$ acids exceeding the aforementioned limits. Neither behenic nor lignoceric acids were detected.
Table 3 shows percentage of SAFA, MUFA and PUFA in selected extra-virgin olive oils

Table 3 Percentage of SAFA, MUFA and PUFA in selected extra-virgin olive oils (mean \pm S.D.)

\begin{tabular}{lccc}
\hline & $\Sigma$ SAFA & $\begin{array}{c}\Sigma \text { MUFA } \\
\%\end{array}$ & $\Sigma$ PUFA \\
\hline $\begin{array}{l}\text { Luccese Olio extra vergine } \\
\text { d'oliva }\end{array}$ & $15.99 \pm 1.02$ & $74.29 \pm 2.15$ & $9.78 \pm 0.86$ \\
Blanqueta extra virgin olive oil & $14.78 \pm 0.99$ & $77.68 \pm 2.43$ & $7.55 \pm 0.69$ \\
Agrocreta extra virgin olive oil & $14.97 \pm 0.84$ & $77.43 \pm 2.19$ & $7.62 \pm 0.61$ \\
\hline
\end{tabular}

Captions: SAFA - Saturated Fatty Acids; MUFA- Mono Unsaturated Fatty Acids;

PUFA - Poly Unsaturated Fatty Acids 
The levels of the above fatty acids are in agreement with findings (Anonymous 1, 1991; Frohn, 2002; Muco et al., 2012; Anonymous 2, 2013; Dalmia and Perkins, 2014; Peri, 2014) reported by various researchers who detected levels of SAFA ranging between $8-25 \%$, contents of MUFA between $55-85 \%$ and amounts of PUFA between of $4-20 \%$.

\section{CONCLUSION}

Investigation of selected extra-virgin olive oils Olio extra vergine d'oliva (LOEVDO), Blanqueta extra-virgin olive oil (BEVOO) and Agrocreta extravirgin olive oil (AEVOO) stored for two years showed significant changes of their properties. Peroxide value grew by $50 \%$ in LOEVDO and BEVOO AEVOO demonstrated even $80 \%$ increase, which proves its limited stability Solely LOEVDO did not exceed the maximum acid value $(<0.8 \%)$. All the samples showed almost identical percentage of monitored fatty acids; BVEOO contained minute amount of lauric acid (C 12:0). During the storage, increase of oleic and stearic acids content was found and decrease of linoleic and palmitic acids levels was observed. SAFA, MUFA and PUFA percentage is in compliance with recommended values.

Acknowledgments: The research this article reports on was implemented under the support of the operational Program called Research and Development for Innovations (Výzkum a vývoj pro inovace) that is co-funded by the European Fund for Regional Development (ERDF) and also subsidized from the state budget of the Czech Republic within the Centre of Polymer Systems Project (reg. n.: CZ.1.05/2.1.00/03.0111) and 2112 -Institutional Support for the Developmen of Research Organizations (Institucionální podpora na rozvoj výzkumné organizace). Project (ID 22738) subsidized by Brno University of Technology, granted by MŠMT ČR.

\section{REFERENCES}

ALBOT, G. 2015. Specialty Oils and Fats in Food and Nutrition: Properties, Processing and Application. Woodhead publising, ISBN 978-1-78242-376-8.20. ANONYMOUS 1. COMMISISION REGULATION 1991 (EEC) No 2568/91 on the characteristics of olive oil and olive-residue oil and on the relevant methods of analysis OJ L 248. https://eur-lex.europa.eu/legalcontent/EN/TXT/PDF/?uri=CELEX:01991R2568-20161204\&from=CS

ANONYMOUS 2. COMMISSION IMPLEMENTING REGULATION (EU) No 299/2013 of 26 March 2013 amending Regulation (EEC) No 2568/91 on the characteristics of olive. https://eurlex.europa.eu/LexUriServ/LexUriServ.do?uri=OJ:L:2013:090:0052:0070:EN:PD F

AOCS OFFICIAL METHOD Ca 5a-40. 2009. Free fatty acids. American Oil $\begin{array}{lll}\text { Chemists' } & \text { Society, } & \text { p. }\end{array}$

BOSKOU, D. 2006. Olive oil: chemistry and technology. 2nd ed. Champaign, Ill.: AOCS Press, 2006. ISBN 9781893997882.

DALMIA, A., PERKINS, G. 2014. Olive oil reference book. PerkinElmer For the better.

http://www.perkinelmer.com/Content/applicationnotes/APP Olive Oil Referenc e_Book.pdf

FROHN, B. 2002. Olivový olej a prírodni léčba: léčeni nemocí a mírněni zdravotnich potiži silou olivového oleje : receptár̆ zdravé kuchyně. Olomouc: Fontána. ISBN 80-7336-016-0.

GROFOVÁ, Z. 2010. Fatty Acid. (Czech) Medicina pro praxi, 7(10): 388-390

CHAKRABARTY, M., M. 2003. Chemistry and Technology of Oils and Fats. Allied Publishers Pvt. Ltd., Pages : viii + 752, ISBN 81-7764-495-5

KALOGEROPOULOS, N., KALIORA, A.C. 2015. Effect of Fruit Maturity on Olive Oil Phenolic Composition and Antioxidant Capacity. Olive and Olive Oil Bioactive Constituents [online]. 123-145 [cit. 2018-11-17]. DOI: 10.1016/B9781-63067-041-2.50011-2.

https://linkinghub.elsevier.com/retrieve/pii/B9781630670412500112

KOIDIS, A., BOSKOU, D. 2015. Virgin Olive Oil. Processing and Impact on Active Components in Food [online]. 267-274 [cit. 2018-11-17]. DOI 10.1016/B978-0-12-404699-3.00032-9. ISBN 9780124046993. https://linkinghub.elsevier.com/retrieve/pii/B9780124046993000329

KORBELÁ $\breve{R}$, J., ENDRIS, Z. 1990. Naše rostliny v lékařství. 7. vyd. Ilustroval Jindřich KREJČA. Praha: Avicenum, 501 p. ISBN 8020100091.

KORIFI, R., PLARD, J., LE DRÉAU, Y., RÉBUFA, C., RUTLEDGE, D.N., DUPUY, N. 2016. Highlighting metabolic indicators of olive oil during storage by the AComDim method. Food Chemistry [online]. 2016, 203, 104-116. https://doi.org/10.1016/j.foodchem.2016.01.137

KOTSIOU, K., TASIOULA-MARGARI, M. 2016. Monitoring the phenolic compounds of Greek extra-virgin olive oils during storage. Food Chemistry [online]. 200, 255-262 [cit. 2018-11-17]. DOI: 10.1016/j.foodchem.2015.12.090. https://linkinghub.elsevier.com/retrieve/pii/S0308814615303678

LOPEZ, S., BERMUDEZ, B., MONTSERRAT-DE LA PAZ, S., JARAMILLO, S., VARELA, L. M., ORTEGA-GOMEZ, A., ABIA, R., MURIANA, F. J.G 2014. Membrane composition and dynamics: A target of bioactive virgin olive oil constituents. Biochimica et Biophysica Acta (BBA) - Biomembranes [online]. 1838(6), 1638-1656 [cit. 2018-11-17]. DOI: 10.1016/j.bbamem.2014.01.007 https://linkinghub.elsevier.com/retrieve/pii/S0005273614000091

MUCO, M., KOPALI, A., MUCO, L. 2012. Physical and chemical characteristics of olive oils from autochthonous albanian olive varieties. Journal of Hygienic Engineering and Design. 60-65. http://www.jhed.mk/filemanager/JHED\%20Vol.\%2012/02.\%20FQS/05.\%20Mari nela\%20Muço.pdf

OREY, C. 2009. Zázračná síla olivového oleje: účinky př́rodního prostředku s desítkami receptů: olivový olej v kuchyni pro krásu a zdraví. Praha: Ikar, 2009. ISBN 978-80-249-1228-8

PERI, C. 2014. The extra virgin olive oil handbook. Chichester, West Sussex, UK: John Wiley \& Sons, ISBN 978-1-118-46045-0.

PISCOPO, A. POI, M. 2012. Packaging and Storage of Olive Oil MUZZALUPO, Innocenzo, ed. Olive Germplasm - The Olive Cultivation, Table Olive and Olive Oil Industry in Italy [online]. InTech, 2012, 2012-12-05 [cit 2018-11-17]. ISBN 978-953-51-0883-2. http://www.intechopen.com/books/olive-germplasm-the-olive-cultivation-tableolive-and-olive-oil-industry-in-italy/packaging-and-storage-of-olive-oil RAFFO, A., BUCCI, R., D'ALOISE. A., PASTORE, G. 2015. Combined effects of reduced malaxation oxygen levels and storage time on extra-virgin olive oil vola-tiles investigated by a novel chemometric approach. Food Chemistry [online]. 2015, 182, 257-267.

https://linkinghub.elsevier.com/retrieve/pii/S0308814615003283

RODRIGUES, F., PIMENTEL, F.B., Beatriz, M., OLIVEIRA, P.P. 2015. Olive by-products: Challenge application in cosmetic industry. Industrial Crops and Products [online]. 70, 116-124 [cit. 2018-11-17]. DOI: 10.1016/j.indcrop.2015.03.027.

https://linkinghub.elsevier.com/retrieve/pii/S0926669015002022

SALEK, R., BUREŠOVÁ, I., KRÁČMAR, S., LORENCOVÁ, E. ZÁLEŠÁKOVÁ, L., DABASH, V. 2017. Evalution of Selected Physicochemical Parameters of Extra virgin Olive Oil Commercialized in the Czech Market and Stored during a Period of 5 Months. Potravinarstvo [online]. 11(1): 664-672. https://dx.doi.org/10.5219/823 